Establishments, International Labor Office (1949); 国際学働局編, 産業安全模範規程 (1951).

23) P. L. Magil, F. R. Holden, C. Ackley, Air Pollution Handbook (1956).

24) L. C. McCabe, Air Pollution (1952).

25) F.S. Mallette, Problems and Control of Air Pollution (1955).
26) The Smog Problem in Los Angels County, Stanford Research Institute (1954).

27) K. Kay, Air Pollution, Anal. Chem. 29, 589 604 (1957).

28）事業場公害関係間題発生および処理概要, 神奈川県商工 部 (1957).

\title{
工場火災と爆 発
}

\section{左右田信一*}

\section{1. 序}

最近安全工学の発達に伴ない，防火，防爆に関する専門書 ${ }^{1210)}$

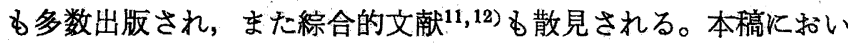
ては，最近の発展の傾向を重点的にしかも簡単に伝えることを目 的とし，詳細はそれぞれの文献を参照されることを希望する。

\section{2. 防火の工学的発展}

然焼現象の結果，直接，間接の損失を生じた場合これを火災と 秝する。然焼現象そのものは自然現象であり，損失の概念は社会 的意識から出発する。燃焼現象発生の原因は，自然的に起ること ああるが，多くは広義の人為的因子によるものである。火炎は出 火に始まり，然焼の拡大深行する。この間に公私の消防活動が 行われ，ある程度の損害をもって消し止める。しかし悪条件が重 なると消防力が敗退して，自然の鎮火を待つ場合もある。被災物 は灭になるか; 全く損傷を受けないか，または変質，变形してあ る程度の価値を残存するかである。

$$
\text { . 火災 } \begin{cases}(1) & \text { 出火 (原因) } \\ \downarrow & (2) \\ \downarrow & \text { 拡大 (媒体, 消防活動の難易) } \\ (3) & \text { 受損 (結果) }\end{cases}
$$

わが国に括ける火災の研究は主として建築関係の人々により行 われて来たので, “防火工学”という語も建築防火，防火都市計画 の意味に使用されていることが多い。その理由は,木造家屋の多い 都市に拈ける消防力弱小による大火の頻発と, 産業の近代化が欧 米にくらへて遅れていたためであると考劣られる。近年高度の資 本集中を必要とする石油化学工業の発達を契機として, セーフテ イエンジニアリングの一部分としての“ファイアセーフティ(Fire Safety)" という語をきくようになった。ファイアセーフティエ ンジニアリング (Fire Safety Engineering) は工場の防火を目 的とし，出火予防を主に，工場全体の機能に対する安全を保持す るための専門技術であり，化学工業においてはとくに種々の重要 な問題がある。

工場火災は，工場経営面のみの損失はもち万ん，企業の公共性 から社会全般に与える間接的損失は测り知れないものがある。そ の意味において経営層が安全に力を入れることは企業の健全な発 達にとって当然のことであり，近代産業において防災はオートメ ーションとともに不可欠の要素となっている。

\footnotetext{
* 損害保險料蜜算定会技術研究室.
}

国家消防本部の統計 $\left.{ }^{13}\right)$ によ れば第 $1 ， 2 ３$ 図のよ 出火件数, 損害額, 死傷者数の いずれも年々増加している。 防火建築の普及, 消防力の增 強に反比例するこれらの事実 は，何を物語るものであるう か。一言にしてい党ば,“ファ イアセーフティ”の欠陥とい うことができる。またわが国 に拈ける工場火災による直接 損害は, 昭和 31 年度に扎い て約 67 億円 (全火災合計の $18.9 \%$ )，件数は 2,826 件(全 火災件数の $10.9 \%$ ) となって いる。そのらち化学工場は全 工場損害額 合計の約 $40 \%$, 件数では約 $20 \%$ となってい る。化学工場の火災損害の大 きいのは，そのプロセスに抽 ける原料, 仕掛品, 製品等の危 険性（質打よび量に和村る）， およびスルホン化，硝化，水 素化, 還元, 重合, 蒸留, 融 解, 乾燥, 粉砕等にお汀る化 学的あるいは物理的原因によ る引火，爆発等の結果による ものであり，更に消火困難な ことにより損害をいっそら大 きくしている。化学工業に拉 ける生産技術の進歩は日進月 歩であり，それに対応して工 場の防火も単に火の用心の掛 声だけではこれを促進するこ とが困難となった。このよう な段階に和いて，防火の問題 もより合理的 (科学的) に, より組織的（系統的）に行わ
第 1 図出火件数

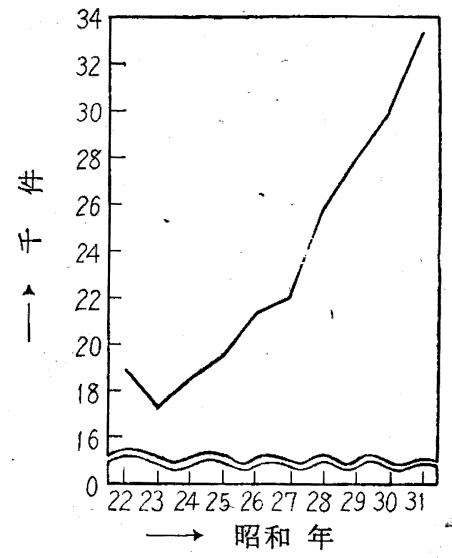

第 2 図損 害 額

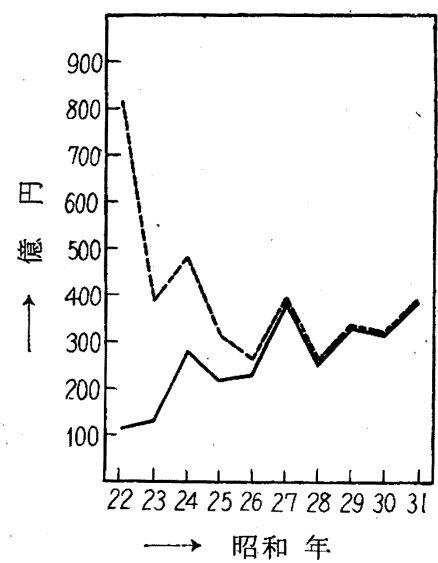

第 3 図 死稘者数

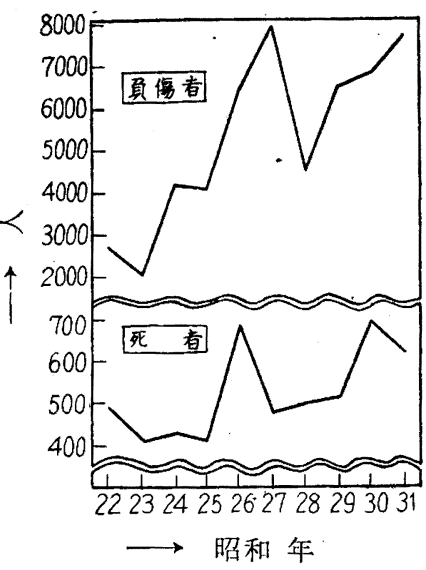


なければいたずらに混乱を招く結果となる。ここに種々の防災に 対する断片的知識の統合集成が必要となる。防火工学もそのよ5 な意味に括いて工場の経営嘪が生産計画と併行して，これを実行 に移さなければ全く意味のないこととなる。

\section{3. 出火防止}

工場火災の自火類焼の割合は，第 1 表のよ5に，他の火災々異 なりほとんどが自火である。とくに，化学工場に括ける出火場所 は，作業場が非常に多く（作業場：付属建物=約 $3: 1$ ), したが って火災危険のある作業場は初めから他の重要な物件から分離す ベきである。

第 1 表 工場火災に拉ける自火類焼の割合

\begin{tabular}{ccccr}
$\begin{array}{c}\text { 昭和 } \\
\text { (年) }\end{array}$ & 普通 & 工場 & 晋通 & 工場 \\
\hline 24 & 44.4 & 91.5 & 55.6 & 8.5 \\
25 & 56.3 & 89.5 & 43.7 & 10.5 \\
26 & 55.0 & 92.2 & 45.0 & 7.8 \\
27 & 62.2 & 93.0 & 37.8 & 7.0 \\
28 & 62.0 & 93.7 & 38.0 & 6.3 \\
平均 & 56.0 & 92.0 & 44.0 & 8.0
\end{tabular}

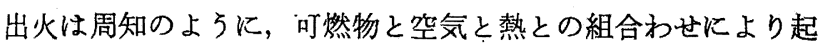
るものであるから，出火防止の根本はそれぞれの完全な分離とい ろことになる。化学工場においては，可然物として，各種可然性 液体, ガスおよび粉体等を多量にしかも高温, 高圧で取扱うこと が多いので，空気あるいは熱源との接触により火災発生の機会が きわめて多い。したがって化学工場における出火防止の最大の要 点は，これらの危険物の管理といらことができる。化学工場に拉 いて取扱われる危険物は，その種類がきわめて多く，これらに関 するハンドブック ${ }^{14)}$ も出版されている。出火防止の第一歩は取扱 5 原料, 一仕掛品, 製品等の危険的特性を十分に知ることであり, 空気との接触を防止するためには，容器，配管等の腐食，破裂， 漏洩等を予防しければならない。そのためには，装置の設計当 初より, 材質, 構造等に打ける必要にして十分な安全性を確保す ることはもちろん，定期的なメタルインスペクション（金属材料 検査) ${ }^{15)}$ を実行すべきである。近代的の大化学工場においては，独 立したメタルインスペクションのグループが編成され，常時検査 を行って安全を期している。ぬた化学工場に扣いては，熱源（火 源）の種類がきわめて多く, 特殊のものが多いので, その接触を 避けるため適切な配虑が必要である。統計的には, 煙草, マッチ による火災事故が最も多いので，危険物を取扱 万場所の火気管理 はいくら厳重にしても，しすぎるということはない。おもな火源 を列挙すれば次のようになる。

(1) 電気装置 (発電機, 変圧器, 電動機等)

(2) 電気機器 (照明器具, 溶接器等)

（3）電熱器 (電気乾燥炉, 電気炉等)

(4) 電気配線

(5) 静電スパーク

（6）各種加熱装置

（7）火花（グラインダー，粉确機等）

（8）摩擦熱（軸受，クラッキ等）

（9）高温体（溶融塩，溶融金属，リベット等）

（10）自然発火（リン，石炭，セルロイド，石灰，油ぼろ等）

(11) 爆発（火薬，花火等）

たとえ危険な火源が存在しても，火源だけでは火災までは発展
しない。化学工場に括ける可燃物は種類も多く，しかも危険な状 態 (分散状態) に扣かれているのが通常であるから, その意味に 扣いても清掃，換気は確実に行5必要がある。

化学工場に打ける出火, 爆発の媒体となるるのの大部分が可然 性ガスおよび引火性液体である。それ故, 出火防止のため, 空気 中に招ける可然性ガス扣よび蒸気の濃度が, 爆発限界内にないよ ろに常に検知寸る必要がある。この目的に対しては, 分析方法が 迅速かつ簡単なことが望まれる。現在実際に使用されているるの には, 携帶用のものでは, 干涉屈折計式のもの (JIS M 7602), 安全燈型ガス検定器 (JIS M 7603), 検知管式のもの (北川式), 然焼式ガス検定器等があり, また固定式自動分析装置を警報装置 に直結したものも利用されている。可然性ガスまたは蒸気の濃度 を測定するには，最す濃度の高い所を選ばなければならない。比 重の相違により，水素，アセチレン，石炭ガス等は上方が，ガソ リン, ベンゼン; エーテル等は床面近くが濃度が高くなり，また 溝, ピット等の凹所には停滞し易いので，とくに注意が必要であ る。

引火性液体を取扱 5 際に，引火または爆発が起るのは，液体の 表面からの蒸発により可然性蒸気が空気と混合するからである。 したがって液体の表面を被覆し，でさるだけ空気と接触しないよ うにすることが必要である。たとえば，少量の引火性液体を運ぶ 場合でも，開放容器を用いないで，必ず蓋の付いた金属製の安全 罐（セーフティカン）を使用すべきである。またタンクあるいは 容器内の液面を測定する場合も，上部の穴から底部までとどくパ イプを設置し，このパイプの中に金属棒を挿入して液高を測るよ うにすれば，露出する液面が少なくなる。

引火性液体を工場内で輸送するには, パイプによるのが安全で ある。引火性液体の輸送, 注入, 排出等に際しては, 静電スパー クが発生し，引火，爆発の危険があるから，容器，パイプ等の金 属部分はすべて確実に接地しなければならない（引火性液体の眝 蔵, 輸送, 使用上注意すべき点は多々あるが，都合上省略

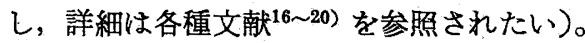

引火性液体の貯蔵タンクでは，タンク内の空気を不活性ガスで 置換し，その酸素濃度をある限界值以下にして拈けば，確実に爆 発を防止できる（たと光ば，酸化エチレン容器内には窒素が充填 されて拈，カーパイトタンク内の空気は，窒素で置換されてい る)。

置換に用いられる不活性ガスは，空気液化分離機のあるところ では窒素が, 炭酸ガスがえやすい土場では炭酸ガスが用いられて いる。まだ然焼排ガス（フリューガス）手利用されている。

\section{4. 拡大防止（損害の局限化）}

出火防止が完全に遂行されれば，拡大防止の対策は全く必要が ないはずであるが，事故は忘れたころに発生するすのであり，ま た化学工場に执いては，初期消火の失敗が多く，そのため全模す ることが多い。その理由は, 引火, 爆発, 沸騰, 蒸発, 溘流等に よる急速な火面の拡大，人員の殺傷，中毒性ガスの発生等により 初期消火が不可能なことが多い。したがって拡大防止すなわち損 害の局限化を考えておかなければならない。火災危険のあるプロ セスは初めから重要な物件から分離すべきことはもちろんである が，生産能率の関係上必ずしも思いどおりには行かないことが夕 い。そのような時には鉄筇コンクリートの防火壁，防爆壁で周囲 
をかこむこともあり，また金属製（ステンレス製）バリケードが 用いられることもある。その他危険簡所およびとくに火熱に対し て損傷を受け易い㯺所のみの周囲に噴霧装置（スプレイヘッド） を設置し保護する。また可燃性液体の眝蔵タンクおよび大量使用 䇢所等においては，必ず防油堤（ダイク）または油返し（カーブ） を設け，火面を局限するようにすべきである。

工場配置は，工場建設の当初において将来の増設計画をも頭に 入れて十分空地を予備しておく必要があり, また気象, 地勢等を 考虑して, 最小限度のスペースと, 冷却水, 消火栓, 電気扣よび 道路等の使用に際して，一方向からだけではなく，少なくとも二 方向から使用できるよ 5 な配慮が望ましい。最近の傾向として， 防災上なるべく建物を建設しないで，屋外設備とし，建物の建設 費で各種の防災設備を行 5 傾向がある。既設の化学工場に执いて は，建物のあるためにかえって引火，爆発の原因をつくり，また 事故発生の際，災害を拡大させる機会をつくっているものがあ る。将来は中央制御室, 事務室等の人のいる場所を除いては建物 を作らないようになるであろろし，また既設の不要の建物（とく に木造）はできるだけとり除いた方がよい。

\section{5. 消灯}

化学工場の火災が問題となるのは, 可燃性液体の火災が多いか らである。可然性液体の消火は，一般に水を使用することが不可 とされている傾向があるが，使用方法，液体の性質等によっては 相当効果のあるものであり，再検討の余地がある。とくに延焼危 険に対する防護 (冷却) 効果は水にまさるものがない。可然性液 体の消火方法について代表的なるのを簡単に列記すれば次のよう になる。

（1）噴靁水（フォグ, スプレイ）燈油, 然料油, 動植物油, 潤滑油等の比較的重い粘稠性の液体の消火に用いられる。ガソリ ン等の軽い液体はすぐに消火することはできないが，質霧は熱を 吸収し他の可然物に火陥の拡大することを防止する。アルコール， アセトン等の水溶性の液体の火災については，表面を十分に希釈 すれば消火することができる。

（2）スプリンクラー 噴霧と類似の効果があるが，消火能力 は小さい。ただ熱を吸収して可然物を冷却するのに役立つが，実 際の消火には他の方法が用いられる。車庫，塗装室，ドラム罐眝 蔵所等の火災に扣いては相当の効果をあげている。

（3）水（ホース）タンクを冷却し，危険な場所に流れ出た 液体を洗い去るのに用いられる。二硫化炭素の火災に際しては静 かに水を注げば，二硫化炭素は水より重いので，水が二硫化炭素 を被覆して消火することができる。

（4）置れ水（ウェットウォーター）アスファルト，タール， ピッチ等の重い液体の火災に対しては, 熱により発泡して消火す る。

（5）自動被临装置（オートマティックカバー）火災に際し，

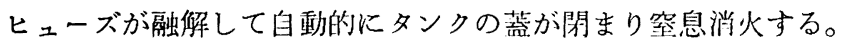
主としてタンク火災に用いられる。

（6）揮発性消火液（四塩化炭素，一塩化一具化メタン等） 小火災に対しては有效であるが，大火災には不適当である。

（7）炭酸カス 比較的小さい，浠い液体のタンク火災には有 效である。

（8）トライケミカル 大火災に対しては不適当，損伤性の大
きいものの消火には有利。

（9）泡（フォーム）最近はほとんどェアーフォームが用い られ，タンクに対しては固定式が多い。アルコール類, 水酢酸, アセトン，セロソルブ，酢酸セロソルブ，グリセリン，石炭酸等 に対しては普通の泡でなく特殊のものが用いられる。

（10）空気かきまぜ 貯蔵タンク等において，眝蔵温度より高 い引火点の液体に対し，底部より王控空気を送入することにより かきまぜ，表面温度を下げ，消火することができる。

最近化学工場においては, 消防ポンプおよび消火栓等による全 体的の消火設備を行った上，更にとくに危険な筒所拉よび重要な 部分のみに局部的に固定式噴霧あるいはエアーフォーム消火装置 を設恔る傾向がある。

\section{6. インスペクション（検査）}

工場の防火を完遂するためには，定期的にインスペクションを 行万必要がある（少なくとも年 4 回以上行うことが望ましい）。 インスペクションの目的は綜合的に防火上の久陷を発見すること にあるが，場合によっては，次のよ5な項目にのみに限定して行 うこともある。

（1）出火危険（生産設储等）

（2）延焼危険（プラントの構造, 配置, 用途等）

(3) 消防火設備（機能検査, 配置等)

(4)防火組織（消防隊の編成，運用等）

(5) 防火計画（新設，改造等）

インスペクションは 1 回行ったならば，それのみで完全である というすのではなく, 欠陥のある所はただちに修正され，インス ペクター（検査員）の衔告は必ず従われなけ机ばならない。そし て次回のインスペクションの際には危険が修正されているかど かを必ず確かめられる。それ故，インスペクターは，プロセスの 細部に通じた，経験と知識の豊富な，判断力の適確な，他人から 信頼されうる人格者でなければならない。

\section{7. 爆 発 災害}

爆発災害は爆発事故の結果であり，必らず損失を伴な弓もので ある。工場内の一隅で爆発が起ったとすれば, そこに働く労働者, 生産施設，原料，仕掛品，製品等は直接損傷を受ける。また間接 的には休業による生産减少，製品の品位低下，外部に対する損害 賠償等数限りない損失を生ずる。したがって，ちょっとした不注 意による爆発事故が，一工場のみならず日本経済全体に影響を与 えることさえある。労働省の統計（昭和 27 31 年）に上れば, 爆発災害発生件数は年平均 133 件, 損害額総計は年平均約 4 億门 となっている。また全工場種別の5ち化学工場は全件数の $1 / 3$ 以 .上，損害額では全損害額の $2 / 3$ 以上を占めている。すなわち化学 工場に抢いては，種々の爆発危険のある物質を取扱い，また爆発

第 2 表 䍶種別爆発災畫発牛件数（昭和 $27 \sim 31$ 年）

\begin{tabular}{|c|c|c|c|c|c|c|c|c|}
\hline $3:$ & 则 & 作数 & $\%$ & $\begin{array}{l}\text { H } \\
\text { fi }\end{array}$ & $\begin{array}{l}\text { 火 } \\
\text { 然 }\end{array}$ & 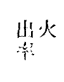 & 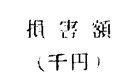 & $\%$ \\
\hline 第一次 & 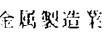 & 109 & 16.3 & 11 & 98 & 10.1 & 116,419 & 5.8 \\
\hline 酷㱔品 & 品裂造箖: & 57 & 8.4 & 8 & 49 & 14.0 & 35,698 & 1.8 \\
\hline 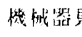 & 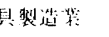 & 122 & 18.5 & 17 & 105 & 13.9 & 275,612 & 14.0 \\
\hline 紀 軄 & I: & 14 & 2.2 & 3 & 11 & 21.4 & 21,226 & 1.1 \\
\hline 化 学 & 工 柴: & 251 & 38.1 & 134 & 117 & 53.4 & $1,377,850$ & 69.9 \\
\hline ガ ス, & 西父柴 & 14 & 2.2 & 10 & 4 & 71.4 & 100,616 & 5.1 \\
\hline その他 & の工 粟 & 92 & 14.0 & 15 & 77 & 16.3 & 44. 421 & 2.3 \\
\hline 合 & 咭 & 659 & 100.0 & 198 & 461 & 28.6 & $1,971,842$ & 100.0 \\
\hline
\end{tabular}


危険のある反応を利用して生

産を行らからである。業種別 に上る爆発災害発生件数, 火 災発生の有無, 出火率, 損害 額を示すと第 2 表のよ5にな る。

また爆発災害の発生件数， 損害額, 死甥者数に括ける最 近の傾向を示したものが，第 $4,5,6$ 図拉よび第 7 図であ る。

これらを検討すると，化学 工場に扸ける爆発災害は他の 業種に比較して特異性が認め られ，また発生件数は漸増の 傾向にある。

爆発災害の特異性は, 第 3 表に見られるように, 月別(季 節別）度数分布に現われてい る。これを火災, 傷害と比較 すれば，災害発生要因として 火災に颃いては気象条件が括 もな要因となっているのに反 し，傷害に扣いては作業条件 （仕事の質，量，扣よび労働 者の生理的, 心理的条件) が おもな要因となっている。爆 発災害はむしろ傷害の傾向に 近いが，気象条件も無視でさ

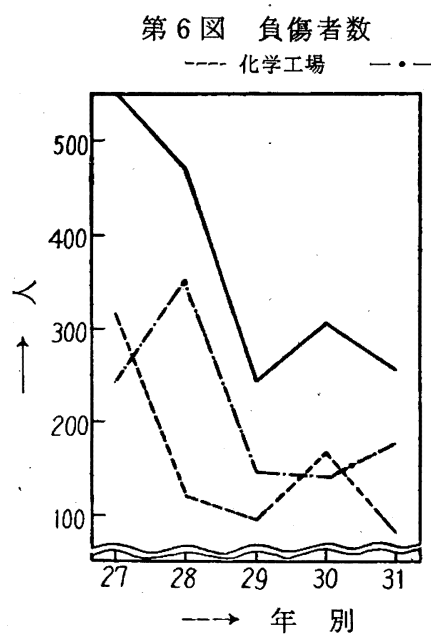

第 4 図 爆発件数

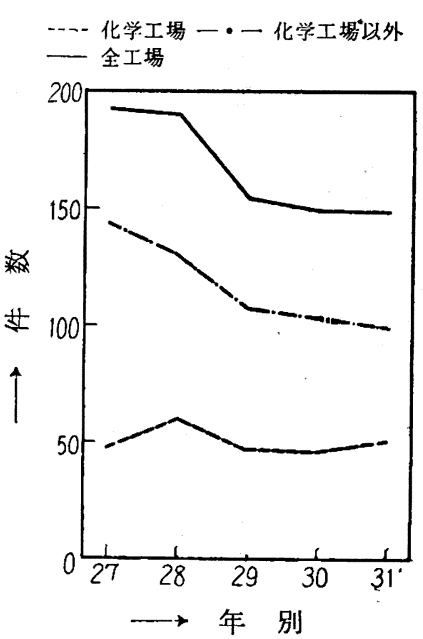

第 5 図損害額

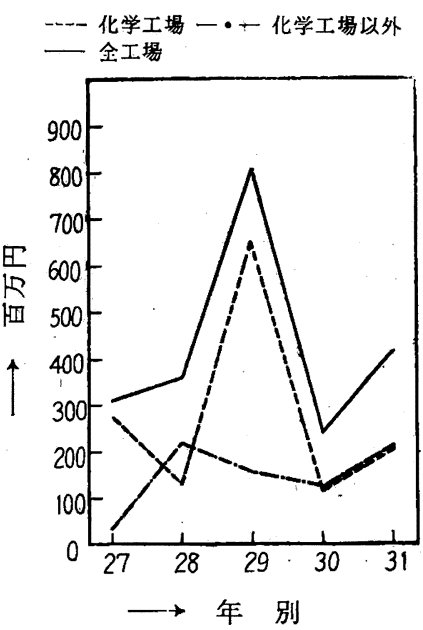

第 7 図死者数

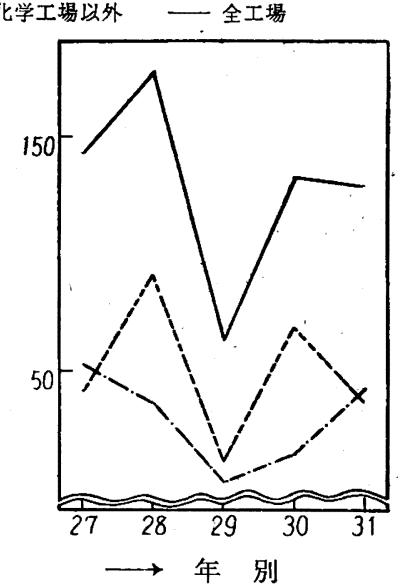

ない。すなわち夏季は冬季に比較して発生件数が明らかに多い。 これは爆発現象そのものよりも作業条件に対する気象の影響が多 分にあるものと推察される（工場火災が夏季に少なく冬季に多い のは気象的要因の結果であり, 傷害が $4,5,6$ 月に多いのは新入 工員の作業に対する未熟練によるものである。爆発災害は第 3 表 のように冬季に少なく，夏季に多い。これは作業員の身心に対す る気温の影響と考えられる。)

\section{8. 防爆}

爆発災害は火災と異なり, 瞬間的に勝負が決定する。火災であ

第 3 表 月別，業種別爆発災害発生件数（昭和 27３1 年）

\begin{tabular}{|c|c|c|c|c|c|c|c|c|c|c|}
\hline & 化 & & & 虎工童 & 機械 & 具工菜 & & の 他 & 全 & 莱 種 \\
\hline 月別 & 件数 & $\%$ & 件数 & $\%$ & 件数 & $\%$ & 件数 & $\%$ & 件数 & $\%$ \\
\hline 1 & 15 & 6.0 & 7 & 6.4 & 14 & 7.9 & 26 & 8.8 & 62 & 7.4 \\
\hline 2 & 20 & 8.0 & 6 & 5.5 & 19 & 10.7 & 32 & 10.8 & 77 & 9.3 \\
\hline 3 & 18 & 7.2 & 11 & 10.1 & 14 & 7.9 & 18 & 6.1 & 61 & 7.3 \\
\hline 4 & 18 & 7.2 & 12 & 11.0 & 16 & 9.0 & 24 & 8.1 & 70 & 8.4 \\
\hline 5 & 24 & 9.5 & 9 & 8.3 & 22 & 12.3 & 30 & 10.2 & 85 & 10.2 \\
\hline 6 & 24 & 9.5 & 9 & 8.3 & 20 & 11.2 & 25 & 8.5 & 78 & 9.4 \\
\hline 7 & 28 & 11.1 & 13 & 11.9 & 16 & 9.0 & 26 & 8.8 & 83 & 10.0 \\
\hline 8 & 32 & 12.7 & 5 & 4.6 & 15 & 8.4 & 27 & 9.2 & 79 & 9.5 \\
\hline 9 & 18 & 7.2 & 13 & 11.9 & 8 & 4.5 & 26 & 8.8 & 65 & 7.8 \\
\hline 10 & 16 & 6.4 & 7 & 6.4 & 14 & 7.9 & 25 & 8.5 & 62 & 7.4 \\
\hline 11 & 20 & 8.0 & 15 & 13.8 & 8 & 4.5 & 17 & 5.8 & 60 & 7.2 \\
\hline 12 & 18 & 7.2 & 2 & 1.8 & 12 & 6.7 & 19 & 6.4 & 51 & 6.1 \\
\hline 璟 & 251 & 100.0 & 109 & 100.0 & 178 & 100.0 & 295 & 100.0 & 833 & 100.0 \\
\hline
\end{tabular}

れば，出火してもそれを消したり，延焼を防いだりする余裕があ るので，防火対策については，現在は出火防止よりるむしろ消， 防火の面に重点が置かれているきらいがある。たとえば工場の一 隅から出火したとしても，ただちに応急的消火が行われ，また， 隣室への延焼防止のため防火戸による遮断を行うことができる。

しかし爆発では，瞬時にして人員を殺傷し，付近の事物を破壞 するので, 事故発生以後の対策はとらてい考えられない。すなわ ち爆発災害に対しては, 爆発事故発生の防止, 破壊, 倒壊, 震々 5, 爆風等に対抗するための構造上の強化および危険の分離に集 中して考えられなければならない。

爆発の原因は，火災と異なり特殊性がある。すなわち爆発する ものがほとんど限定されているからである。過去の統計による と, ガス爆発では, アセチレン, 水素, 石炭ガス, 塩素水素混合 物, 酸素等, 引火性液体による爆発では，ガソリン，ベンゼン， 二硫化炭素, アルコール等, 固体による爆発では, 煙火（原料, 製品等) 各種火薬類, 硝化綿, セルロイド, 金属ソーダ, ニトロ 化合物, ジアゾ化合物, 過酸化物等が多い。したがって,このよう な爆発性危険物を取扱 5 作業場, 倉庫等に拈いては, 厳重な防災管 理が必要である。火薬類, 高圧ガスについては通産省の法規21 22) があり，種々の防災上の規定が行われているが，他の業種の工場 に执いて，これに相当するものがないので，自主的の防爆対策 が必要である。またこれらの工場におけるる爆発災害が比較的多い ことを付記して，関係諸賢の防災に対する関心がよりいっそう高 掦されることを期待するものである。

\section{一文献一}

1) G. Armistead, Safety in petroleum refining and related industries (1950).

2) G. E. Stecher, Fire prevention and protection fundamentals (1953).

3) J. H. Perry, Chemical Engineers' Handbook p. 1847 1884 (1950).

4) W. Staniar, Plant Engineering Handbook p. 173 266 (1950).

5) J. R. Davis, Industrial Plant Protection (1957).

6) J.Guelich, Chemical Safety Supervision (1956).

7) N. F. P. A., Handbook of Fire Protection (1957).

8) N. F.P. A., National Fire Codes I VI (1957).

9) 横浜大学工学部, 安全工学 (1957).

10）日本火災学会，火災便覧（1955）.

11）北川徹三 “安全工学”; 高圧ガス協会誌 21 , No. 3, 4, 5, 6, 10 (1957).

12) 化学工業社, 産業々安全 (1956).

13）国家消防本部，火炎年報（第 13 号）(1957). 
14) N.I.Sax, Dangerous properties of industrial materials (1957).

15) J.F.Strachan, Petroleum refinery engineer's handbook (1955).

16) Factory Insurance Association, Safeguarding flammable liquids (1953).

17) Factory Mutual Engineering Division, Storage tanks for flammable liquid (1953).
18) Factory Mutual Engineering Division, Flammable liquids drumstorage (1953).

19) National Safety Council, "Data Sheets".

20) Manufacturing chemists association, "Chemical Safety Data Sheets".

21) 通座省, 火薬類取締法の解説 (1955).

22）通産省，高圧ガス取締法の解説 (1955).
高圧ガス 工業の安全

\section{緒}

言

ここで高圧ガスとは便宜的な取扱いかたであると解して，圧力 の限定についてはとくに詮索しないことにする。高圧ガスの安全 な製造，運搬，眝蔵，消費などを目的として制定されている日本 の高圧ガス取締法では，常用の温度で $10 \mathrm{~kg} / \mathrm{cm}^{2}$ (ゲージ圧力)以 上の圧縮ガスと, 常用の温度で $2 \mathrm{~kg} / \mathrm{cm}^{2}$ (ゲージ圧力) の压力と なる夜化ガス（ただしアセチレンを含む）を高圧ガス取楴の対象 としているのに対し，たとえば，アメリカの I.C.C. (Interstate Commerce Commission) は $70^{\circ} \mathrm{F} て ゙ ~ 40 \mathrm{psi}$ (絶対圧力) 以上の 圧力を示す圧縮ガスか， $130^{\circ} \mathrm{F}$ で $104 \mathrm{psi}$ (絶対圧力) 以上の圧

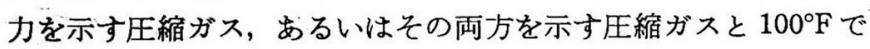
$40 \mathrm{psi}$ (絶対圧力) の蒸気圧を有する可燃性液体を対象とするよ5 に必ずしも一定でない。日本では 1922 年以来高圧ガス取締法が 実施されているので，安全を目的とするこの法にしたがうのが便 利のよ5に思われる。高圧ガスはその性質から漏れや噴出を起し やすい状態にあって, ガスは可然性, 有毒であることが多い上に, 高圧容器の破裂, 爆発をる伴ない, 人的, 物的な被害を与えるた め, ことに法律によって規制し取締っているわけである。また， 事実高圧ガスによる災害が発生するので災害を防止し, 公共の保 一安維持のため取締法が制定されたのである。しかし, 既成の高圧 ガス工業では, 一応そのガスについて製法や物理的, 化学的な特 性が研究され明らかにされているはずで，その安全の基準も取締 法に明確に示されている。それでも高圧ガスによる災害は跡をた たない。しかし，それら災害の大半は当然守るべき取締法の規制 を無視したり，をた無知粗暴な取扱いによって引き起されたもの が多い。このよ5な余り同情できない事故災害※をここに再録し てる有意義に思われないので触れないことにする。

高圧ガスの安全については, むしろ反応一生成系, 触媒, 反応 条件などについて未知の研究を行う場合, 多くの不碓定要素が含 まれているので，それだけに十分な注意，準備，防護施設が必要 である。しかし既成の高圧工業においても，法律に準拠して絶対 に安全であるといら保証はえがたい。また法によってえられる安 全は必ずしも能率的でないこともあり，あるいは安全な取扱法が 確立されていない場合もありえよう。たとえばアセチレンの大量

* 工業技術院東京工業試験所第 6 部.

※たとえば高压ガス協会訫の災害事故速報を参照されたい。

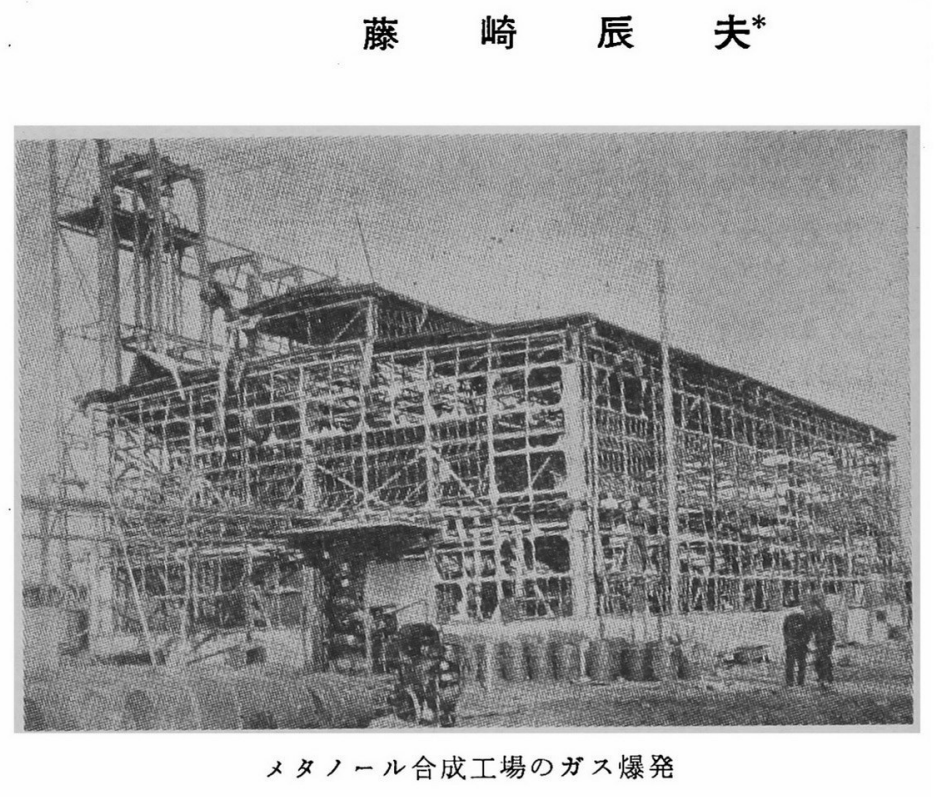

の安全な圧縮や圧縮アセチレンの管輸送の方法, 液体シアン化水 素の長期貯蔵, 炭酸ガス除去の高圧水洗塔の腐食とそれに伴な5 災害, 空気液化分離器の爆発防止, メラミンの高圧合成に伴な5 異常圧力の発生, 耐熱性の金属材料, 高温高圧で $\mathrm{H}_{2}, \mathrm{~N}_{2}, \mathrm{NH}_{3}$ に耐える金属材料, 合成筒や圧縮ガス容器の寿命の判定, クリー プの問題など多くの問題がある。ここでは高圧ガス工業の安全に 関する原則的な事項 ${ }^{1)}$ を簡単に述べると同時に, 高圧ガス工業の 安全と密接な関係のある三, 三の困難な問題を指摘していっそ5 安全な新しい高圧ガスの斐法や進歩した取扱法の発展を期待した w。

\section{高圧ガス取締法について}

この表題のもとでは取締法について触れる必要があると思われ るので紹介にとどめる程度に述べる。1951 年改正された法では それより 30 年前に制定された旧法の法体系の整備, 技術基準の 再検討が行われ, 旧法は全面的に改正されている。この法では高 圧ガスの製造から販売, 眝蔵, 移動, 取报, 消費, 容器の製造に 至る広い範网の規定があり,さらに高王ガス取締施行規則によっ て具体的な基準が示されている。またそのほかに告示，通牒など が追加されていて相当に複雑である。

高圧ガスの製造業者は従来から事業所ごとに定められた区分に したがって高压ガス作業主任者舴状の交付を受けた者のうらから 